\title{
Dynamic Reciprocity and Ontological Affinity in the Pauline Account of Solidarity
}

\author{
Prof. Grant Macaskill, University of Aberdeen
}

\section{Abstract:}

This article suggests that the dynamic elements of gift-giving and reciprocity, which are incisively re-evaluated in John Barclay's study Paul and the Gift, might fruitfully be combined with the classical Incarnational understanding of the union of natures to better our understanding of Paul's soteriology. Setting Paul's account of salvation within the framework of the wider New Testament, the article highlights the presence of key elements that might best be articulated in terms of the dual kinship of Jesus with both God and humanity and that require some discussion of the ontology of the one who saves. When Paul speaks of the solidarity that exists within the Christian community, he does so in a way that links it to the presence of the Spirit, by whom we participate in the oneness of God through the one mediator; his development of this emphasis draws heavily upon the Shema, which Jewish traditions associate with the distinctive 'being' of God.

Keywords: Barclay, John; Paul; two-natures Christology; ontology; soteriology; union with Christ.

John Barclay's recent study, Paul and the Gift, ${ }^{1}$ pays sustained and careful attention to concepts at work in Paul's soteriology that we might, for want of a better word, label as 'dynamic': the paired expressions 'exchange' and 'reciprocity', even if reconceived by Paul in highly distinctive ways, are suggestive of movement and activity between persons. They may be associated with the 'solidarity' between the parties involved, ${ }^{2}$ but always in ways that are linked to the processes of 'handing over',

\footnotetext{
${ }^{1}$ John M.G. Barclay, Paul and the Gift (Grand Rapids: Eerdmans, 2015).

2 The word 'solidarity' is only used by Barclay a few times in the book, but its occurrence in his discussion of Schwartz's thesis concerning the Jewish 'rejection of
} 
'receiving', 'returning', and 'passing on'. A gift is given to those who are incapable of reciprocating, whose personal capital does not warrant such a gift, and who are therefore 'unfitting' recipients, but by means of what they receive, they are transformed; the gift brings about a 'fittingness' in its recipients to enjoy solidarity with God and with each other within the redeemed community. This fittingness is, itself, conceived in ethical and dynamic ways; those transformed by the gift perform and relate differently as agents.

Barclay is generally less interested in what might be labelled as 'ontic' or 'ontological' considerations, although there is some discussion of these in relation to the work of Bultmann, ${ }^{3}$ where they operate at a fairly low level of describing the human 'condition'. Barclay's own work is in line with the drift of most current Pauline scholarship towards seeing Paul's soteriology as largely concerned with divine action and not with categories of nature or being, except perhaps at the low level of identifying the problem of sin with 'flesh' ( $\operatorname{sarx})$. More obviously ontological categories may be at work elsewhere in the New Testament, notably in the Johannine literature, but they are not typically understood to be significant in the thought of Paul. ${ }^{4}$ In Barclay's reading of Paul, matters of ontology are simply treated as if they are peripheral; consequently, there is little sense in his study that Paul might be interested in the 'natures' of Christ, as soteriologically significant realities.

reciprocity' (Paul and the Gift, p.39-45) in favour of an 'ideology of solidarity and equality' is interesting:

It is not clear why 'solidarity' and 'equality' are in principle opposed to 'reciprocity' since, as we have seen, the normal give-and-take- among kin, and the friendship of equals extolled by Aristotle, both operate in expectation of reciprocal exchange (p.40)

${ }^{3}$ See Paul and the Gift, p.136.

4 There is some willingness to speak of 'relational ontology', which links the being of entities to their relationships with other things or persons. On the application of this category to Paul, see Susan Eastman, Paul and the Person: Reframing Paul's Anthropology (Grand Rapids: Eerdmans, 2017). There is, of course, a significant backdrop to this work, as ontic and ontological issues have been, by turns, popular and unpopular in biblical and theological scholarship. 
By contrast, my own work on New Testament soteriology $y^{5}$ has made much of how the concept of redemptive solidarity_kinship — is linked to the sharing of natures: Jesus Christ shares a nature with us and shares a nature with God, a dual kinship that makes possible his mediatorial function. This is an understanding that I trace widely through the New Testament, finding it to be more explicit in some parts of the corpus and less explicit in others; even where less explicit, though, it appears to be assumed.

Such a reading of the New Testament is not typical of biblical scholarship and, in my case, reflects a deliberate commitment to reading the primary material in a way that is informed by Patristic theology and its uptake in the later theological traditions. I consider this to be no more anachronistic than applying the categories of contemporary anthropology to the biblical material: if done in a way that is careful to allow the New Testament material to speak with its own distinctive voice, then bringing such external material to the text can be heuristically valuable. The Patristic study of the New Testament gives us categories and concepts of theology, particularly as these bear on the believer's participation in the life of God, that might helpfully inform our reading of the text, even if they are not obviously derived from the text itself. For present purposes, what is most valuable is the recognition that the assumption of human nature by the one who continues to share in the nature of God is crucial to salvation. A given biblical author may not himself articulate this point explicitly, but it can nevertheless be identified as a crucial assumption in their rendering of the gospel.

My intention in this article is not to critique Paul and the Gift, or to suggest that my emphasis on natural solidarity is better than Barclay's emphasis on relational dynamics. I am basically persuaded by Barclay's key claims and, indeed, consider these to constitute some of the most important research findings of modern New Testament scholarship. Rather, I want to start with the assumption that the argument of Paul and the Gift is correct and to reflect on how paying some attention to ontological elements in Paul's writings that are largely passed over by Barclay might further nuance it and might, perhaps, invite some further reflection for subsequent volumes or even editions of this book. Much of what I say will, I suspect, sound quite

5 Particularly, my Union with Christ in the New Testament (Oxford: Oxford University Press, 2013). See also my forthcoming, Living in Union with Christ: Paul's Gospel and Christian Moral Identity (Grand Rapids: Baker, 2019). 
traditional or even old- fashioned, but this should not be surprising: on many key points, Paul and the Gift reasserts more traditionally Lutheran readings of Paul against the dominant paradigms of the last half century, and this invites some reflection on whether some of the underlying convictions of those traditional readings - concerning the natures of Christ and the operation of the Spirit-might also be reaffirmed as elements in Paul's thought, and not dismissed as later projections of the theological tradition.

The article will have three core parts. In the first part, I will offer some brief reflections on some common elements of tradition in the wider New Testament which I think reflect a common conviction that Jesus is to be identified both as creature and Creator, and that this dual identification is vital to his role as mediator of salvation. In the second part, I will consider some of the elements in Paul's writings that I argued in my study of Union with Christ in the New Testament ${ }^{6}$ to reflect something similar, an underlying (if also underdeveloped) assumption of ontological affinity between the Redeemer and the redeemed. In the third part, I will consider some of the ways in which Christ and the Spirit are represented as generating solidarity within the church, but in ways that draw on Jewish traditions about God's distinctive 'being'. Paul considers Christian solidarity to be a basic element of our constitution in union with Christ, a oneness that proceeds from the oneness of the God to whose indivisible life we are now united through the mediator.

\section{The Wider New Testament and the Dual Identification of Christ}

My study of Union with Christ in the New Testament was shaped by an intentional commitment to reading the parts of the New Testament in relation to each other, as a necessary part of both the historical and the theological task. While we must not flatten the differences between the various authors, as if they all say the same thing, we must reflect on how they may cohere and how each may inform or even constrain the theological significance of the other. If the author of the Fourth Gospel considers it to be soteriologically significant that the Word became Flesh, what bearing does

\footnotetext{
${ }^{6}$ Grant Macaskill, Union with Christ in the New Testament (Oxford: Oxford University Press, 2013).
} 
this have on how we read Paul within the historical context of early Christianity and how we appropriate his thought to the theological task?

This involves some reflection on the kinds of parallels that may be identified across the New Testament and on whether these can be traced back to common concepts and traditions or to common Scriptural reading strategies. One notable example of such parallels is that Jesus is commonly identified with a particular part of creation, the 'stone' or 'rock' that is laid in Zion and that serves as the unifying point of the temple. ${ }^{7}$ This identification is associated with a cluster of texts that use the words 'stone' and/or 'rock' in relation to the themes of election and rejection, specifically Psalm 118 (LXX, 117):22, Isaiah 8:14-15 and 28:16, possibly supplemented by Daniel 2:34-35, 45. The overlapping vocabulary allows these passages to be read together, according to the principles of Jewish exegesis, something that can be seen explicitly in 1 Peter 2:4-8 and probably also in Matt 21:42-44/Luke 20:17-18. ${ }^{8}$ They are also encountered individually, however, in various places (Mark 12:10, Acts 4:11, Romans 9:32-33), something that suggests they were diffusely applied within early Christianity to the figure of Christ. ${ }^{9}$

This may parallel their use in Jewish messianic traditions. Jesus, for example, quotes Psalm 118:22 and then elaborates it with Isaiah 8:15 in the Parable of the Tenants, as represented by Matthew 21 and Luke 20, applying the texts to the rejection of the Son. This may well reflect a punning of the words 'eben ('stone') and

\footnotetext{
${ }^{7}$ I put it in these terms to recognize that this stone may variously be identified as 'cornerstone' or 'capstone'; both have a unifying function.

${ }^{8}$ There are debates over the place of Isaiah 8 and Daniel 2 in the Parable of the Tenants, but these reflect the limited awareness of Jewish reading strategies that characterises most New Testament scholars.

${ }^{9}$ There have been suggestions that these texts circulated in testimonia collections within the early church. See, for example, Klyne Snodgrass, 'The Christological Stone Testimonia in the New Testament,' Ph.D dissertation, University of St Andrews, 1973.
} 
ben ('son'), something that is attested in other Messianic readings of the Psalm 118:22, which likewise understand the 'Eben to be a figure of the Ben. ${ }^{10}$

Collectively and separately, the texts also render an expectation that God's work of salvation will involve the building of a new temple in which he will dwell. Within the New Testament, this concept is widely taken up in relation to the community of believers as the true temple, though in ways that are not necessarily homogeneous or even consistent. ${ }^{11}$

The identification of Jesus as the cornerstone or capstone invokes this widely found idea of the eschatological temple wherever it is found, and does so in a way that understands Jesus to be a part of the creaturely reality of the earthly temple, along with the community associated with him: whatever its connection to the heavenly temple might be, ${ }^{12}$ this is something that exists on earth. He is 'the living stone' around whom the temple is build and, as we come to him, we are built 'as living stones' into a spiritual house (1 Pet 2:4-8). Such language indicates that his nature and our natures correspond.

This correspondence is essential to the imagery, but in a way that is often assumed or left tacit, rather than being made explicit, as it is in both the Fourth Gospel (where the Word becomes flesh), or in the Epistle to the Hebrews, where it is pivotal to the soteriological role of the great High Priest that he be made like his brothers in every respect (Heb 2:17). This statement in Hebrews rests on an underlying notion of kinship within Judaism, whereby every high priest chosen from among men (ex anthrōpōn) is appointed to act on behalf of men (hyper anthrōpōn) in relation to God, to offer gifts and sacrifices for sins (Heb 5:1). The repetition of anthrōpōn with its different controlling prepositions is important here, establishing a close association between the nature or origin of the high priest and the mediatory tasks that he performs. Only one who is from humanity can act for humanity.

10 The Aramaic targum translation of Psalm 118:22, for example, changes 'stone' to 'child' and the Songs of David text from the Cairo Genizah applied the verse to David. See my discussion in Union with Christ in the New Testament, pp.168-9.

${ }^{11}$ See chapters 6 and 7 of Macaskill, Union with Christ in the New Testament.

12 The heavenly temple is the focus of Hebrews and the idea of such a heavenly reality, or even of heaven as a temple, is widely found in Jewish texts of the period. 
But in Hebrews, this solidarity is realised by one who is first identified with God, the creator and sustainer of all things (Heb 1, esp vs 1-3): he is the Son, who is (hos $\bar{o} n$ ) the effulgence of God's glory and the imprint (charakter) of his nature (hypostasis). It is crucial to the account of salvation in Hebrews that Jesus is understood to share a nature with us, but also to share a nature with God. This is paralleled in the imagery that represents the Christian community as the eschatological temple: Jesus is identified not just as a creaturely part of the temple, but also with the one who dwells in it. Ephesians 2:20 identifies Jesus as the cornerstone of the temple, but later in the same epistle $(3: 17)$, the author speaks of Christ dwelling in our hearts; the construction uses the verb katoikeo, which is cognate to the noun used in Eph 2:22 of the church as the dwelling place for God's Spirit (katoikêtēion). As we will see in the next section, Paul also identifies the Spirit who dwells in our heart with both Christ and the one who raised Christ from the dead. So, Christ is identified at once with a created part of the temple of which believers are also parts, the crucial stone, and with the One who dwells in that temple. ${ }^{13}$

Some of these texts are fairly late in the development of the New Testament, but they draw upon a tradition that can be traced back to Jesus, which Paul himself draws upon and participates in. This invites us to ask how Paul's identification of Jesus, both with respect to his people and with respect to God, might have figured within his soteriology and whether it involves a tacit or explicit set of beliefs about natures and kinship. This is not to minimise the relational or narratival elements of the 'Christ event', but to suggest that they may rest upon a set of assumptions about what is involved in this: the gift that is given may have substance, and that substance may be significant.

\section{Solidarity of Natures and the Gift.}

Paul may not have anything quite as developed as what we have just seen in, for example, Hebrews (assuming that Hebrews is not Pauline ...), but there are suggestions that he considers some kind of natural solidarity to be crucial to salvation and vital to the Christ gift.

\footnotetext{
${ }^{13}$ Isaiah 8:14-15 may also play a role in this, since there 'the LORD of Hosts' is described as becoming 'a sanctuary.'
} 
For God has done what the law, weakened by the flesh, could not do: by sending his own Son in the likeness of sinful flesh (en homoiōmati sarkos hamartias), and to deal with sin, he condemned sin in the flesh, so that the just requirement of the law might be fulfilled in us, who walk not according to the flesh but according to the Spirit. (Rom 8:3-4)

What is important about this is not just the reference to the Son being sent in the likeness of sinful flesh' (vs 3), which might be read in a number of ways, but the fact that this same 'flesh' is the location of the decisive act against sin: 'he condemned sin in (en) the flesh.' The redeemer and the redeemed share a substance, and this is crucial to his capacity to act redemptively in their behalf. This natural solidarity is essential to 'the gift that is not like the trespass' (Rom 5:15-17), the gift that brings righteousness to many. A similar concern to highlight some kind of natural solidarity is seen in Galatians 4:4-5, which I will render quite woodenly to bring out this emphasis:

But when the fullness of time came, God sent his Son, born of a woman, born under the law, in order those under the law to redeem, in order that we might receive adoption.

If I were a strong believer in chiasmus, I might see one here, but a less debateable observation can be made: the flow of words emphasises that for the Son to redeem those under the law, he had to share in their condition, not just legally, but also naturally — he had to be 'born of a woman'.

Both texts also, however, pair this emphasis on solidarity with 'sinful flesh' to a distinctive solidarity with God: the one who is sent, born of a woman in the likeness of sinful flesh, is 'his Son'. For the sake of time, I am simply here going to assume that the arguments for an early high Christology-differently developed by Bauckham, Hurtado, Newman and others - are correct, and that this title is deployed within a broader pattern of identifying Jesus as God. Within this pattern, the title 'Son' uses kinship imagery, specifically filial imagery, to speak of the solidarity 
between God and Christ. This natural solidarity, moreover, is the pattern for the new dynamic solidarity between God and his people that emerges from the Son's redemptive work: they are 'adopted', and come to participate in his relationship with the Father, crying 'Abba' (Rom 8:15; Gal 4:6). It is crucial to this, however, that he is the Son in an unqualified sense. By contrast, those who are saved become sons by adoption (Rom 8:15, Gal 4:5), though this is not reduced to a cold legal concept (note the shift to describing them as 'children' in 8:16-17). This is the substance of the great exchange: 'he became what we are, so that we might become what he is.'

It is worth noting that this dual solidarity within the Christ event-with us, on one hand (or in one nature) and with God, on the other-feeds through to one of the most obviously participatory images in Paul's writing, the one we have seen to be widely found in the New Testament: the community as temple. Jesus is part of the temple that enjoys the presence of God; he is its foundation (1 Cor 3:11). Yet he is also the one who dwells in it. This latter point emerges more fully in the debated epistles, Colossians and Ephesians (e.g., in Eph 3:17), but it can be seen also in the primary Pauline letters - for example in 2 Cor 12:9, where Paul speaks of the power of Christ 'dwelling' in him - and can be considered more prominent still if we recognize the Pauline identification of the Spirit as 'the Spirit of his Son' (Gal 4:6). That allows us to see the references to the Spirit that dwells within the temple (1 Cor 3:16) as identifying that Spirit with Christ.

But you are not in the flesh; you are in the Spirit, since the Spirit of God dwells in you. Anyone who does not have the Spirit of Christ does not belong to him. (Rom 8:9)

Paul may not make explicit the categories of natural kinship that bind Jesus to us and to God, but they are arguably assumed in the basic structures of his thought.

\section{The Spirit of the One God and the Oneness of the Community}

This brings us to the third part of the paper, and to the ways in which unity within the body is represented in relation to solidarity with God, Christ and Spirit. It is important that the 'oneness' of the Christian community is located prepositionally: it is 'in 
Christ'. That basic, inclusive reality relativizes all other identity markers ('There is no longer Jew or Greek, there is no longer slave or free, there is no longer male and female; for all of you are one in Christ Jesus', Gal 3:28) and contextualises all that the members of the community do. Ethically, this does a lot of work for Paul, including in 1 Corinthians, where he applies it extensively to the various forms of disunity visible in Corinth, associated with factionalism and the distribution of honour. It is interesting, though, that his ethical logic does not represent this oneness as a desideratum, but as a fact: precisely because we are one, disunity is an atrocity, an aberration. It contradicts our being in Christ.

In the flow of 1 Corinthians 8-13 (although the threads can be traced back to the beginning of the epistle), this logic is flexibly applied to various situations, but it is anchored in Paul's modified reiteration of the Shema in 8:6:

Yet for us there is one God, the Father, from whom are all things and for whom we exist, and one Lord, Jesus Christ, through whom are all things and through whom we exist.

Here, we have what is often described as a 'binitarian' or Christological expansion of the Shema, but the word 'one' runs as a motif through the chapters that follow, where it is applied also to the Spirit, demanding that we consider whether it might be better to label this as trinitarian (even if incipiently so):

For in the one Spirit we were all baptized into one body-Jews or Greeks, slaves or free- and we were all made to drink of one Spirit (1 Cor 12:13)

Note here the overlap of language with the 'in Christ' statement of Gal 3:27 and 28 Jews and Greeks, slaves and free, all are one as a consequence of their baptism-and note, too, that what we are dealing with is something paralleled in Galatians with the sending of the Son:

${ }^{4}$ When the fullness of time had come, God sent his Son, born of a woman, born under the law ... ${ }^{6}$ And because you are children (lit. 'sons'), God has sent the Spirit of his Son into our hearts, crying, "Abba! Father!" (Gal 4:4, 6) 
The gift that is constituted by the Christ-event, then, is one that brings about filial solidarity with the one God, who is represented as actively present within his people in the Spirit, by which (or 'by whom') we participate in his oneness. The unity of the Christian community, then, is a function of the oneness of the God in which it pneumatically participates. Its disunity is not an unfortunate hurdle to be overcome by learning to 'dance' in unity, but is an atrocity precisely because the body of Christ is one, as it participates in the One God through the One Mediator, by the One Spirit.

It is important to note that this is a distinctive development of a tradition of reflection on the Shema and the Divine Name that can be found more widely in the Judaism of the period (and, for that matter, in the Judaism that has followed). The Shema, of course, indicates that the one named by the Tetragrammaton is to be worshipped exclusively because he is uniquely God. His people cannot divide their service among a range of deities who rule over different parts of the cosmos, because the LORD is one-he is indivisible, and must be indivisibly worshipped. The significance of the divine name itself is disclosed in Exodus 3:14, in a passage that seems to explicate the significance of the Tetragrammaton, as it is associated with the verb hayah, 'to be'.

${ }^{13}$ But Moses said to God, 'If I come to the Israelites and say to them, "The God of your ancestors has sent me to you," and they ask me, "What is his name?" what shall I say to them?' ${ }^{14}$ God said to Moses, 'I AM WHO I AM (ehyeh asher ehyeh).' He said further, 'Thus you shall say to the Israelites, "I AM has sent me to you."' (Ex 3:13-14)

The imperfect ehyeh can be understood quite flexibly in relation to time: while normally translated 'I am', it can also be translated as 'I will be'. Jewish readers developed interesting interpretative traditions around this temporal quality of the divine name. In Targum Pseudo Jonathan, for example, there is a modestly elaborated version of the disclosure of the name in Ex 3:14 ('I am what I am and I will be what I will be ${ }^{14}$ ), which is expanded in the translation of Deut 32:39:

\footnotetext{
${ }^{14}$ See Robert J. Wilkinson, Tetragrammaton: Western Christians and the Hebrew Name of God. From the Beginnings to the Seventeenth Century (Leiden: Brill, 2015), pp. 182-3.
} 
Behold now, that I am he who am, and who was, and I am he who will be, and there is no other God beside me: I, in my Word, kill and make alive (my translation)

Because the verb identifies God in terms of his unique 'be-ing', it allows Jewish writers to understand the categorical uniqueness of God, linked to the exclusivity of the monotheistic demands, in what we might see as ontic terms. Philo, for example, speaks of God as ho $\bar{o}$, and understands this title to reflect the self-sufficiency and perfections of his being. This differentiates God from the world, but also defines the nature of his relationship to it:

We all know that before the creation of the world, God was sufficient unto Himself, and that after the creation He remained the same, unchanged. Why then did he make the things that were not? Why, save because He was good and bountiful (Mut. 46). ${ }^{15}$

This is interesting, because it is not just description of non-contingency, but of a positive plenitude that is characterised by goodness. God is, he is One, and he is good: because these things are true, the world exists.

We may not be in the territory of substance metaphysics, but there is a distinctive pre-occupation with how God's 'be-ing' is different from the 'being' of everything else. This, indeed, can be seen in the 'anîh hulegō eimi sayings of Deuteronomy 32:32 and Isaiah, which are commonly understood to lie in the background of the Johannine 'I Am' sayings: they set God in a category apart from all other things, on the basis of his unique relationship to time and the world of time-bound things. ${ }^{16}$ Paul, as with all who stand in the biblical tradition, recognises that things are made with particular natures, according to particular 'kinds'(Genesis 1:11, 12, 21-25; cf. 1 Cor 15:38-41). God, however, is in a category of his own. He is, in a way that nothing else is. This is

${ }^{15}$ See Peter Frick, Divine Providence in Philo of Alexandria (TSAJ 77. Tübingen: Mohr Siebeck, 1999), p. 62.

${ }^{16}$ See my, 'Name Christology, Divine Aseity and the I Am Sayings in the Fourth Gospel', Journal of Theological Interpretation 12 (2018), pp. 217-241. 
why he is to be worshipped with the undivided heart, soul and strength; this is why it is right to say that YHWH is One.

So, when Paul invokes the Shema in 1 Cor 8:6, modifying it to accommodate the identity of Jesus Christ, and then continues to evoke it in the chapters that follow, linking it to the presence of the One Spirit within the body of Christ, he draws upon a widely found tradition that reflects on the uniqueness of the divine being, YHWH, ho $\bar{o} n$. Yet he does so in a way that represents Jesus as a participant in that oneness, distinctively and uniquely as 'mediator', and then similarly represents the Spirit, who actively realizes our identification with this mediator. The Oneness of God is now expected to characterise the community identified as the body of Christ, because members of this body have been made to drink of the One Spirit of the One God. Their active solidarity - with each other and with God-emerges from two united ontic realities: the oneness of the God in whose life they now participate by the Spirit, and the existence of the one who mediates this reality, who is simultaneously identified with God and with those who participate in God's life through him, born of woman, born under Law. He is uniquely kin to both and, hence, uniquely capable of acting as mediator.

\section{Concluding Comments}

This leads me to offer some concluding comments on how these elements of the Christ gift, and the solidarity that is associated with it, might be brought into conversation with Paul and the Gift. My basic point is that the gift which is given and which generates reciprocity is constituted by and in Christ's person; his 'natures' (however we might define that word) bear on its significance and its operation. What is 'received', moreover, is the Spirit of the Son, whose reality is inseparable from being of the one whose identity governs the genitive (Gal 3:2, read with 4:6). If I were to level a criticism at Paul and the Gift, it would be for the relatively slender space devoted to discussion of the Spirit; while we should always engage with scholarship for what it does, rather than what it does not do, this does seem to me to be a matter of proportion that underplays the importance of the Spirit in Paul's account of gift. Furthermore, I think it undervalues the significance of the identification of the Spirit with both the Son and the one who raised Christ from the dead (Romans 8:9-11), 
something that moves us in the direction of thinking about God in the terms of classical trinitarianism and demands that we think again about the nature of God. Arguably, Paul's development of the Shema to accommodate his new identifications of God does exactly this: it takes a tradition of thinking about how God's 'be-ing' is unique and re-conceives it to accommodate Jesus and the Spirit.

More constructively, though, what I have discussed here might offer some fruitful lines of reflection on Paul's thought and that of his receivers in the theological tradition. We may be speaking of a dynamic activity or process of 'giving', but we are also speaking of something or someone that is the substance of that gift. Paying attention to what is given, and its constitution, is an important corollary of the study of exchange. For various reasons, New Testament scholars have shied away from speaking about ontology or about natures/substances. These are considered to be alien to the thought-world of the New Testament writers. Perhaps, though, this has overlooked something genuinely significant to the soteriology of the writers, including Paul.

This brings us back to Luther, as a practical theological exegete. Barclay's study has given us a renewed appreciation of Luther's appropriation of Paul; it is no longer possible to dismiss Luther's account of justification by faith as a projection, in the way that so much New Testament scholarship has done over the last half century. We might extend this to the range of ways that Luther's account of justification is itself shaped by a sense of the one in whose person the gift is constituted, and the ways that his personal constitution shapes the constitution of the gift. Perhaps with Luther, as with Paul, this in an underlying assumption that is not visible everywhere in the same way, but is necessary nonetheless to make sense of his soteriological account. Mannermaa and others in the Finnish School have drawn attention precisely to such elements in his writings, but have been criticised for their interpretation of these as representing something participationist rather than forensic or imputational. Perhaps we might revisit these claims, in the context of the renewed appreciation of Luther as exegete and theologian. I leave the last words to Luther, then, quoting his 1514 Christmas sermon, a beautiful articulation of the Great Exchange that draws upon its formulation in the Patristic tradition: 
The Logos puts on our form and pattern, our image and likeness, so that it may clothe us with its image, its pattern, and its likeness.' ${ }^{17}$

17 The translation is Tuomo Mannermaa's, 'Why is Luther so Fascinating? Modern Finnish Luther Research', in Carl Braaten and Robert W. Jenson, eds., Union with Christ: The New Finnish Interpretation of Luther (Grand Rapids: Eerdmans, 1998), p. 11. 